\title{
Novel and atypical pathways for serotonin signaling
}

\author{
Joël Bockaert $^{1^{*}} \quad$ Carine Bécamel $^{1} \quad$ Séverine Chaumont-Dubel $^{1} \quad$ Sylvie Claeysen $^{1} \quad$ Franck Vandermoere $^{1}$ \\ Philippe Marin ${ }^{1}$ \\ ${ }^{1}$ The Institute of Functional Genomics (IGF), University of Montpellier, CNRS, INSERM, Montpellier, France
}

\begin{abstract}
Serotonin (5-HT) appeared billions of years before 5-HT receptors and synapses. It is thus not surprising that 5-HT can control biological processes independently of its receptors. One example is serotonylation, which consists of covalent binding of 5-HT to the primary amine of glutamine. Over the past 20 years, serotonylation has been involved in the regulation of many signaling mechanisms. One of the most striking examples is the recent evidence that serotonylation of histone H3 constitutes an epigenetic mark. However, the pathophysiological role of histone H3 serotonylation remains to be discovered. All but one of the 5-HT receptors are G-protein-coupled receptors (GPCRs). The signaling pathways they control are finely tuned, and new, unexpected regulatory mechanisms are being uncovered continuously. Some 5-HT receptors $\left(5-\mathrm{HT}_{2 \mathrm{C}}, 5-\mathrm{HT}_{4}, 5-\mathrm{HT}_{6}\right.$, and 5- $\mathrm{HT}_{7}$ ) signal through mechanisms that require neither G-proteins nor $\beta$-arrestins, the two classical and almost universal GPCR signal transducers. 5- $\mathrm{HT}_{6}$ receptors are constitutively activated via their association with intracellular GPCR-interacting proteins (GIPs), including neurofibromin 1, cyclin-dependent kinase 5 (Cdk5), and G-protein-regulated inducer of neurite outgrowth 1 (GPRIN1). Interactions of 5-HT 6 receptor with Cdk5 and GPRIN1 are not concomitant but occur sequentially and play a key role in dendritic tree morphogenesis. Furthermore, 5- $\mathrm{HT}_{6}$ receptor-mediated G-protein signaling in neurons is different in the cell body and primary cilium, where it is modulated by smoothened receptor activation. Finally, 5- $\mathrm{HT}_{2 \mathrm{~A}}$ receptors form heteromers with $\mathrm{mGlu}_{2}$ metabotropic glutamate receptors. This heteromerization results in a specific phosphorylation of $\mathrm{mGlu}_{2}$ receptor on a serine residue $\left(\mathrm{Ser}^{843}\right)$ upon agonist stimulation of $5-\mathrm{HT}_{2 \mathrm{~A}}$ or $\mathrm{mGlu}_{2}$ receptor. $\mathrm{mGlu}_{2}$ receptor phosphorylation on $\mathrm{Ser}^{843}$ is an essential step in engagement of $\mathrm{G}_{\mathrm{i} / \mathrm{o}}$ signaling not only upon $\mathrm{mGlu}_{2}$ receptor activation but also following 5-HT $\mathrm{H}_{2 \mathrm{~A}}$ receptor activation, and thus represents a key molecular event underlying functional crosstalk between both receptors.
\end{abstract}

\section{Keywords}

Serotonin; serotonylation; receptor; GPCR interacting protein; heteromerization

\section{Peer Review}

The peer reviewers who approve this article are:

1. Mark M Rasenick, Department of Physiology and Biophysics, Department of Psychiatry, University of Illinois at Chicago, and Jesse Brown VAMC Chicago, IL, 60612, USA

Competing interests: No competing interests were disclosed.

2. Javier González-Maeso, Department of Physiology and Biophysics, Virginia Commonwealth University School of Medicine, Richmond, VA 23298, USA

Competing interests: No competing interests were disclosed.

3. Amitabha Chattopadhyay, CSIR-Centre for Cellular and Molecular Biology, Hyderabad, India Competing interests: No competing interests were disclosed. 
*Corresponding author: Joël Bockaert (joel.bockaert@igf.cnrs.fr)

Competing interests: The authors declare that they have no competing interests.

Grant information: The authors are supported by grants from University of Montpellier, iSITE Montpellier University of Excellence (MUSE), Centre National de la Recherche Scientifique (CNRS), Institut National pour la Santé et la Recherche Médicale (INSERM), and Agence Nationale de la Recherche (ANR, contracts n ${ }^{\circ}$ ANR-17-CE16-0013-01, ANR-17-CE16-0010-01, and ANR-19-CE18-0018-02).

The funders had no role in study design, data collection and analysis, decision to publish, or preparation of the manuscript.

Copyright: (C) 2021 Bockaert J et al. This is an open access article distributed under the terms of the Creative Commons Attribution License, which permits unrestricted use, distribution, and reproduction in any medium, provided the original work is properly cited.

How to cite this article: Bockaert J, Bécamel C, Chaumont-Dubel S, Claeysen S, Vandermoere F and Marin P. Novel and atypical pathways for serotonin signaling. Faculty Reviews 2021 10:(52) https://doi.org/10.12703/r/10-52

Published: 01 June 2021, Faculty Reviews 10:(52) https://doi.org/10.12703/r/10-52 


\section{Introduction}

The serotonin (5-HT) biosynthetic pathway is an ancestral biological process present in unicellular systems such as cyanobacteria, green algae, and fungi and is conserved in both invertebrates and vertebrates ${ }^{1}$. In contrast, 5-HT receptors have not been found in plants and appeared along with synapses 600 million years $\mathrm{ago}^{1}$. Therefore, it is not surprising that some 5-HT biological effects that do not require 5-HT receptors have been established during evolution. One of the most fascinating discoveries of the last 20 years is the demonstration that 5-HT can bind covalently to the primary amine of glutamine in proteins ${ }^{2,3}$. This covalent modification called serotonylation is implicated in many biological mechanisms, such as epigenetics, both at the periphery and in the brain ${ }^{3-7}$ Thus, 5-HT controls cellular signaling events by acting either extracellularly via membrane receptors or intracellularly via serotonylation, even though some serotonylation events occur extracellularly (Figure 1). This dual 5-HT control of cell signaling is shared with dopamine, histamine, and noradrenalin ${ }^{6,7}$. It illustrates the proposal from François Jacob that evolution tinkers with a limited number of disposable genes and molecules to ensure the greatest number of biological functions ${ }^{8,9}$.

5-HT finely controls an increasing number of functions including highly complex processes, such as anxiety, mood, learning, memory, cognition, social interactions, sleep, and appetite, but also more unexpected ones, such as shell formation in bivalves ${ }^{10}$. This large diversity of 5-HT functions has been made possible by selecting a large number of receptors that finely regulate diverse cellular signaling pathways, and 5-HT is certainly one of the neurotransmitters able to activate the largest number of receptor subtypes (17 identified in vertebrates). All are G-protein-coupled receptors (GPCRs), except for the five 5-HT receptors, which are cation channels ${ }^{11}$. Twenty years ago, the

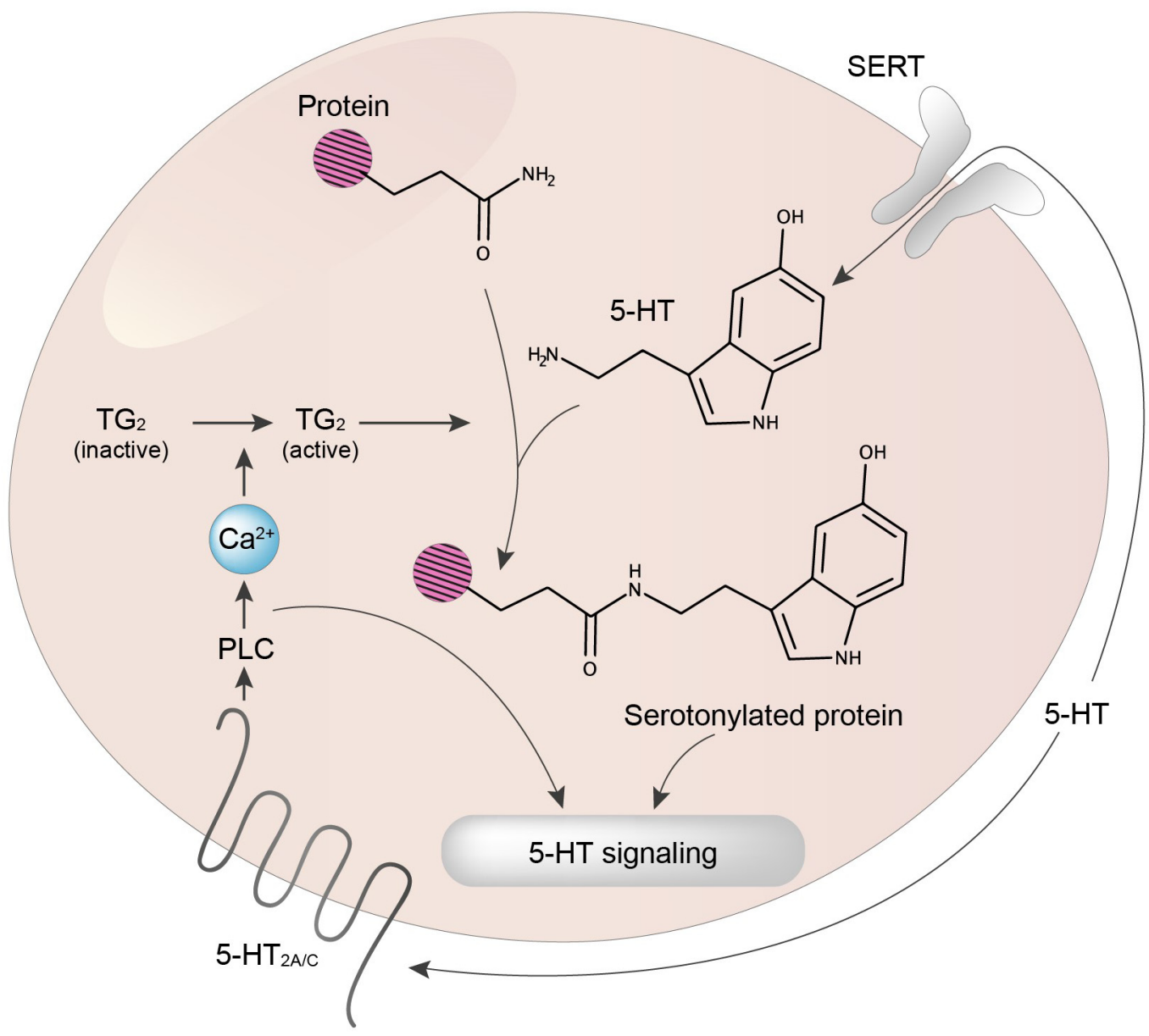

Figure 1. 5-HT signaling via G-protein-coupled receptors (GPCRs) and serotonylation. 5-HT controls cell signaling via its cognate receptors (mostly GPCRs) and intracellularly via transamidation (serotonylation) of specific proteins. Note that extracellular proteins can also be serotonylated (not illustrated). Owing to the hydrophilic nature of $5-\mathrm{HT}$, serotonylation is believed to occur only in cells expressing the serotonin transporter (SERT). In the example illustrated in the figure, 5- $\mathrm{HT}_{2 \mathrm{AC}}$ receptor stimulation by 5-HT induces activation of phospholipase $\mathrm{C}$ (PLC), and thereby an increase in intracellular $\mathrm{Ca}^{2+}$ concentration, a process leading to a full activation of the transglutaminase TG2. 
signaling mechanisms associated with 5-HT GPCRs were thought to be simple ${ }^{12}$. The $5-\mathrm{HT}_{1}$ receptor family was known to be coupled to $G_{i}$ proteins, thus inhibiting adenylyl cyclase (AC), the $5-\mathrm{HT}_{2}$ family to $\mathrm{Gq}$ (activate phospholipase $\mathrm{C}$ ), and $5-\mathrm{HT}_{4}, 5-\mathrm{HT}_{6}$, and $5-\mathrm{HT}_{7}$ receptors to Gs (activate AC), while the coupling mechanisms of $5-\mathrm{HT}_{5}$ receptors remained elusive. Our current knowledge of 5-HT receptor signal transduction is now much more complex than this initial view and is in constant evolution ${ }^{11,13}$. Since 5-HT receptor-mediated signaling has been extensively reviewed elsewhere ${ }^{11,13-17}$, we will focus here on the most original and intriguing signaling mechanisms that have been recently described.

Receptor-independent 5-HT signaling: serotonylation The covalent binding of polyamines or biogenic monoamines (serotonin, dopamine, noradrenalin) to glutamine was described a long time ago $^{3}$. Enzymes responsible for this biochemical reaction, called transamidation, are transglutaminases (TGs) ${ }^{3}$. Seven TGs exhibiting mainly intracellular location have been identified, the most abundant and ubiquitous one being TG2. Blood coagulation factor XIII, once activated by thrombin during coagulation to give factor XIIIa, also displays extracellular TG activity ${ }^{3}$.

The first physiological function depending on serotonylation was described by Dale et al. in 2002-2003 3 . This group of investigators showed serotonylation by factor XIIIa of several procoagulant proteins, including fibrinogen, von Willebrand factor, fibronectin, factor $\mathrm{V}$, and thrombospondin on the surface of activated platelets, which leads to the accumulation of aggregated proteins in the extracellular matrix ${ }^{18}$. Fibrin is also cross-linked by factor XIII, thereby increasing clot resistance $^{19}$. Following the observation that Bordetella pertussis toxin acts as a transglutaminase that covalently binds polyamines to small G-proteins ${ }^{20}$, Walther et al. discovered that small G-proteins (RhoA and Rab4) are serotonylated (likely by TG2) in platelets, a process making them constitutively active in a GTP-bound form ${ }^{2}$ (Figure 2). RhoA reorganizes the cytoskeleton, whereas Rab4 stimulates the exocytosis of $\alpha$-granules, which contain proteins involved in coagulation. A rise in intracellular $\mathrm{Ca}^{2+}$ is necessary to activate $\mathrm{TG}^{2}$. This $\mathrm{Ca}^{2+}$ elevation is due, at least in part, to the activation of platelet $5-\mathrm{HT}_{2 \mathrm{~A}}$ receptors ${ }^{21}$. Thus, 5-HT acts both extracellularly and intracellularly during platelet activation and the serotonin transporter (SERT) is needed for intracellular accumulation of 5-HT required for serotonylation ${ }^{5}$.

Pulmonary hypertension involves proliferation and contraction of arterial smooth muscles. Proliferation of arterial smooth muscles is under the control of serotonylated $\mathrm{RhoA}^{22,23}$, whereas their contraction is modulated by serotonylated actin and $\operatorname{myosin}^{24}$ (Figure 2). Fibronectin serotonylation has also been involved in pulmonary hypertension ${ }^{3}$, a process favored by the up-regulation of $\mathrm{TG}^{25}$. The remodeling of cardiac valve interstitial cells, a heterogeneous population of cells responsible for maintaining the structural integrity and normal functioning of the valve, is key to understanding mitral and aortic valve dysfunctions in pulmonary hypertension. The role of $5-\mathrm{HT}_{2 \mathrm{~B}}$ receptor activation by $5-\mathrm{HT}$ in this pathology caused by fenfluramine treatment is well known, but serotonylation of filamin-A has also been implicated ${ }^{26}$ (Figure 2). Pancreatic $\beta$-cells capture extracellular 5-HT via SERT. Cytosolic 5-HT in turn accumulates with insulin in secretory vesicles through vesicular monoamine transporter 2 (VMAT2). Exocytosis of vesicles and co-release of 5-HT and insulin also require serotonylation of two small G-proteins, Rab3a and

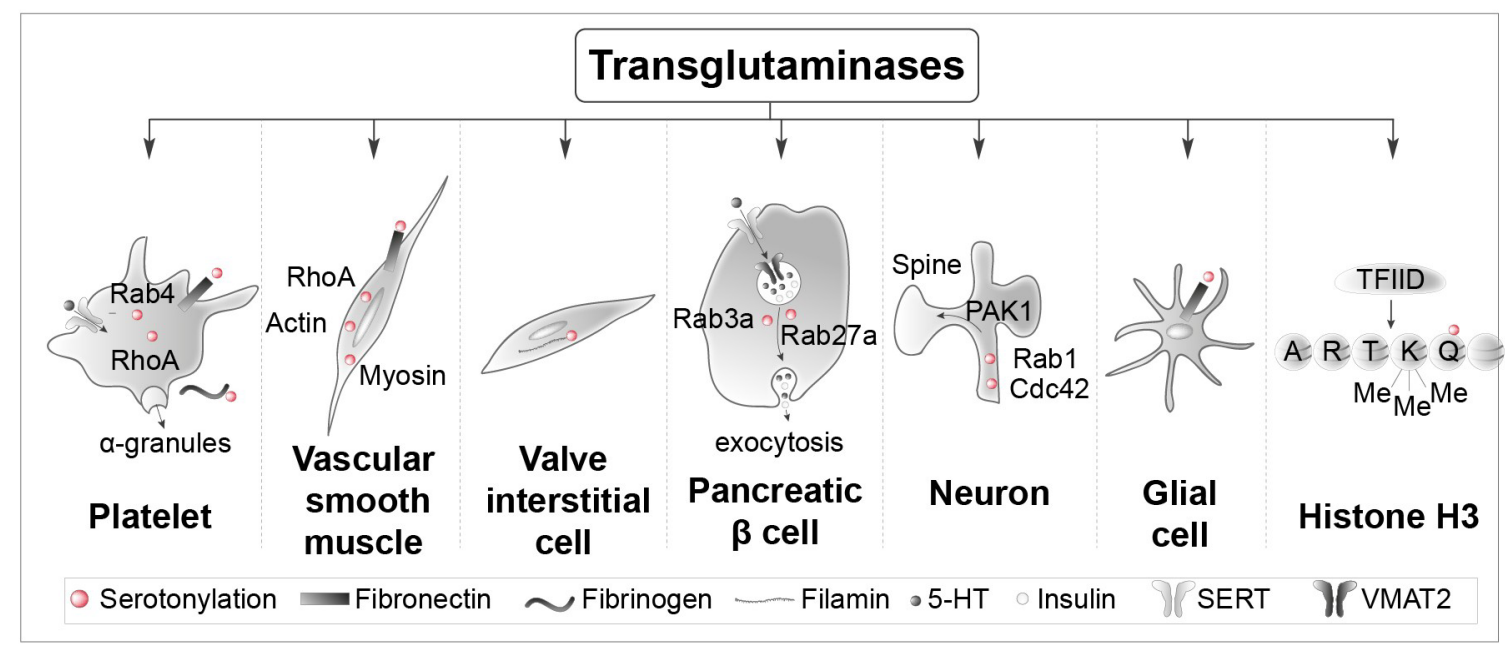

Figure 2. Specific proteins serotonylated by transglutaminases in different cell types. Examples of intracellular and extracellular serotonylated proteins in platelets, vascular smooth muscle cells, valve interstitial cells, pancreatic $\beta$-cells, neurons, and glial cells are illustrated. The right panel shows serotonylated histone H3 at position 5 (Q5ser) by transglutaminase 2 (TG2) predominantly in combination with trimethylation of adjacent lysine $(K) 4$, resulting in the double epigenetic mark H3K4me3Q5ser. SERT, serotonin transporter; TFIID, transcription factor II D; VMAT2, vesicular monoamine transporter 2. 
$\operatorname{Rab}_{27} \mathrm{a}^{27}$ (Figure 2). Stimulation of $5-\mathrm{HT}_{2 \mathrm{~A} / 2 \mathrm{C}}$ receptors by 1-[2,5-dimethoxy-4-iodophenyl]-2-aminopropane (DOI) induces $\mathrm{Ca}^{2+}$-dependent TG activation, serotonylation of Rac1 and Cdc42, and Pak1 stimulation in cortical neurons, a process leading to an increase in dendritic spine size (Figure 2) ${ }^{28}$. This identifies serotonylation as a novel signaling pathway underlying the influence of 5-HT on dendritic spine morphology and plasticity ${ }^{28}$. Fibronectin and other proteins are likewise transamidated by biogenic amines including 5-HT in glial cells (Figure 2), but few data are published on the role of this chemical modification in this cell type ${ }^{29}$.

The most exciting discovery on transamidation is its role as an epigenetic mark controlling gene expression ${ }^{6,7}$. Serotonylation of histone $\mathrm{H} 3$ on glutamine (Q5) has been found in several organs producing 5 -HT, including the brain and the gut, and in different animal species ${ }^{4}$ (Figure 2). 5-HT and other monoamines are present in the nucleus ${ }^{30,31}$ and can thus serve as substrates for transamidation of histones. The nuclear membrane is permeable to monoamines ${ }^{32}$, which allows a rapid equilibration of extravesicular monoamines between the cytoplasm and the nucleus ${ }^{30}$. Nuclear 5-HT is mobilized and released upon stimulation of dorsal raphe-containing brain slices ${ }^{30}$.

Histone $\mathrm{H} 3$ serotonylation requires trimethylation of the neighboring lysine (K4) and occurs during the differentiation of human pluripotent stem cells into 5-HT-containing neurons. This histone $\mathrm{H} 3$ modification is enriched in gene promoters and facilitates binding of the general transcription factor TFIID and gene transcription ${ }^{4}$. Similarly, dopaminylation of Q5 of histone $\mathrm{H} 3$ was found during cocaine withdrawal. This promotes gene expression in ventral tegmental area (VTA) neurons, increases their excitability, and favors drug-seeking behavior in rats $^{6,7}$.

\section{G-protein-independent signaling at 5-HT G-protein- coupled receptors}

Like many proteins, GPCRs can adopt different active and inactive conformations ${ }^{33-35}$. Some active conformations favor activation of one or several G-proteins, whereas others favor GPCR association with $\beta$-arrestins ${ }^{35}$. Biased ligands can stabilize either one or several G-protein-preferring conformations, or $\beta$-arrestin-preferring conformations, or conformations favoring both G-protein- and $\beta$-arrestin-dependent signaling. In addition, some GPCRs, including 5-HT receptors, trigger signaling events without any involvement of G-proteins or $\beta$-arrestins, that can thus be designated as "non-G-protein/ $\beta$-arrestin" signaling. These particular signaling mechanisms can result from either receptor stabilization in a specific active conformation by binding to an agonist or, in some cases, agonist-independent (constitutive) receptor activation.

While many GPCRs are known to stimulate the MAP-kinase Erk1,2 pathway through the sequential activation of G-proteins and $\beta$-arrestins ${ }^{36}$, two 5-HT receptor subtypes have been shown to engage the Erk1,2 signaling pathway through G-protein- or $\beta$-arrestin-independent mechanisms. Stimulation of Erk1,2 by the $5-\mathrm{HT}_{2 \mathrm{C}}$ receptor does not require G-proteins and entirely depends on the concomitant recruitment of $\beta$-arrestin and calmodulin $(\mathrm{CaM})$ by the receptor ${ }^{37}$. In light of the direct interaction of purified calmodulin ( $\mathrm{CaM}$, bound to $\mathrm{Ca}^{2+}$ ) with $\beta$-arrestin ${ }^{38}$ and $\mathrm{CaM}$ dimerization ${ }^{39}$, it has been proposed that $\beta$-arrestin might be recruited via $\mathrm{CaM}$ bound to the receptor, which might also stabilize the $5-\mathrm{HT}_{2 \mathrm{C}}$ receptor/ $\beta$-arrestin complex (Figure 3). Consistent with this hypothesis, Erk1,2 activation by the $5-\mathrm{HT}_{2 \mathrm{C}}$ receptor is unusually long lasting (up to 3 hours) when compared to other GPCRs $^{37}$. This contrasts with the activation of Erk1,2 signaling by the $5-\mathrm{HT}_{4}$ receptor, which lasts only 20 minutes and is independent of both G-proteins and $\beta$-arrestins but requires Src activation (Figure 3$)^{40}$. In the Caco-2 epithelial intestinal cell line, 5- $\mathrm{HT}_{4}$ receptor-mediated $\mathrm{Src}$ activation also leads to $\mathrm{PLC} / \mathrm{Ca}^{2+}-\mathrm{CaM}$-dependent inhibition of the $\mathrm{Na}^{+} / \mathrm{H}^{+}$exchanger ${ }^{41}$.

The 5- $\mathrm{HT}_{4}$ receptor displays a high level of constitutive activity. Constitutively active $5-\mathrm{HT}_{4}$ receptors directly bind to the $\alpha$-secretase ADAM10 and stimulate its activity ${ }^{42}$, thus favoring non-amyloidogenic cleavage of the amyloid precursor protein (APP, Figure 3). Stimulation of ADAM10 by constitutively active 5- $\mathrm{HT}_{4}$ receptors is independent of $\mathrm{Gs}$ and cAMP production ${ }^{42}$. The conformation of constitutively active 5-HT $\mathrm{H}_{4}$ receptors associated with ADAM10 likely differs from the conformation of constitutively active $5-\mathrm{HT}_{4}$ receptors coupled to Gs. Indeed, whereas agonist-independent 5-HT receptor-operated Gs signaling is inhibited by the inverse agonists RO 116-0086 and RO 116-2617, these compounds are inactive on receptor-dependent ADAM10 activation ${ }^{42}$. Chronic administration of RS 67333, a 5- $\mathrm{HT}_{4}$ receptor agonist, or donecopride, a multi-target compound able to both inhibit acetylcholinesterase and activate $5-\mathrm{HT}_{4}$ receptors, decreases amyloid load and Tau hyperphosphorylation as well as learning and memory deficits in mouse models of Alzheimer's disease ${ }^{43,44}$.

Native 5-HT6 receptors exhibit a high level of constitutive activity at $\mathrm{Gs}$ signaling. The $5-\mathrm{HT}_{6}$ receptor also constitutively activates cyclin-dependent kinase 5 (Cdk5)/Cdc42 signaling through a mechanism involving agonist-independent association of $\mathrm{Cdk} 5$ and its activator p35 to the receptor C-terminus and receptor phosphorylation on a Ser residue $\left(\mathrm{Ser}^{350}\right)$ by associated $\mathrm{Cdk}^{45}$ (Figure 3). This pathway is engaged by mutated $5-\mathrm{HT}_{6}$ receptors unable to activate Gs, suggesting the presence of at least two different active receptor conformations able to activate Gs and Cdk5 signaling, respectively ${ }^{14,45}$. Agonist-independent $5-\mathrm{HT}_{6}$ receptor-operated $\mathrm{Cdk} 5$ signaling finely tunes cortical neuron migration and promotes the initiation of neurite growth ${ }^{45-47}$.

Likewise, constitutively active $5-\mathrm{HT}_{7}$ receptors directly bind to and activate $\mathrm{Cdk} 5$ in a G-protein-independent manner (Figure 3$)^{48}$. In a mouse model of tauopathy overexpressing a human Tau mutant known to be associated with frontotemporal dementia $\left(\mathrm{R}^{406} \mathrm{~W}\right)$, constitutively active $5-\mathrm{HT}_{7}$ receptors physically associated with $\mathrm{Cdk} 5$ induce hyperphosphorylation of Tau and the formation of highly bundled Tau structures ${ }^{48}$, 


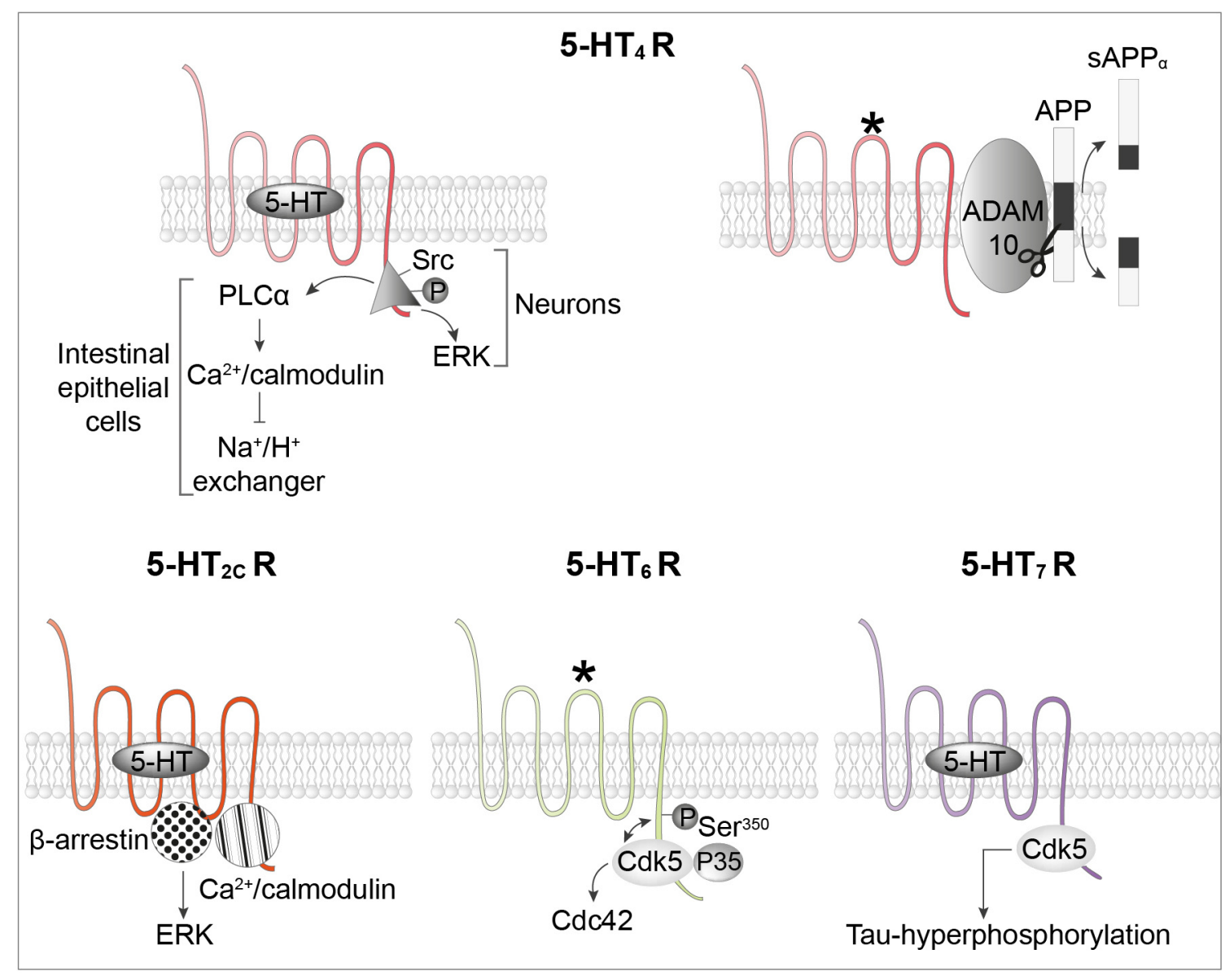

Figure 3. Non-G-protein signaling at 5-HT receptors. Top: the 5- $\mathrm{HT}_{4}$ receptor engages Erk1,2 signaling in neurons through a Gs- and $\beta$-arrestin-independent mechanism that requires activation of the non-receptor tyrosine kinase Src. In the intestinal epithelial Caco-2 cell line, 5- $\mathrm{HT}_{4}$ receptor-mediated Src activation leads to phospholipase $\mathrm{C}(\mathrm{PLC}) / \mathrm{Ca}^{2+}$-calmodulin-dependent inhibition of the $\mathrm{Na}^{+} / \mathrm{H}^{+}$exchanger. ${ }^{*}$ Constitutively active receptors. Bottom left: the $5-\mathrm{HT}_{2 C}$ receptor engages Erk1,2 signaling in neurons through a G-protein-independent, $\beta$-arrestin-dependent mechanism that requires physical association of calmodulin with the receptor's C-terminal domain. Bottom, middle: the $5-\mathrm{HT}_{6}$ receptor activates the cyclin-dependent kinase 5 (Cdk5)-Cdc42 signaling pathway in an agonist-independent manner through a reciprocal interplay between the receptor and associated Cdk5, by which Cdk5 bound to the receptor C-terminal domain phosphorylates the receptor on Ser ${ }^{350}$, a necessary step in Cdk5-dependent activation of Cdc42. Bottom, right: the 5-HT receptor binds to and activates Cdk5 signaling, a process leading to Tau hyperphosphorylation. APP, amyloid precursor protein.

suggesting that the $5-\mathrm{HT}_{7}$ receptor-Cdk5 signaling pathway may be a new target in tauopathies.

\section{Constitutive activation of $5-\mathrm{HT}_{6}$ receptor by interacting proteins}

Another example of molecular tinkering of $\mathrm{GPCRs}^{8}$ is their ability to be activated by both agonists and their interaction with intracellular proteins. Twenty years ago, we described the first example of agonist-independent activation of GPCRs (the group I metabotropic glutamate receptors $\mathrm{mGlu}_{1}$ and $\mathrm{mGlu}_{5}$ ) by an intracellular GPCR-interacting protein (GIP), Homerla. Homerla is the product of an immediate early gene induced in activated neurons ${ }^{49}$. Constitutively active $\mathrm{mGlu}_{1} / \mathrm{Homer}_{\mathrm{la}}$ and $\mathrm{mGlu}_{5} /$ Homer la complexes are implicated in a large series of homeostatic plasticity events ${ }^{50-54}$.

More recently, we reported the association of $5-\mathrm{HT}_{6}$ receptor with many GIPs. These include proteins of the mechanistic target of rapamycin (mTOR) pathway (mTOR itself, Raptor, which together with mTOR is part of the mTOR complex 1 , the Ras GTPase-activating protein [Ras-GAP] neurofibromin 1, and Vps34, a class III phosphatidylinositol 3-kinase). Further studies revealed that mTOR activation by $5-\mathrm{HT}_{6}$ receptor has a deleterious influence upon cognition in rodent models 
of schizophrenia and cannabis abuse during adolescence ${ }^{55,56}$. Three 5-HT 6 receptor-interacting proteins were found to activate $5-\mathrm{HT}_{6}$ receptors in an agonist-independent manner (Figure 4) ${ }^{13}$. The first one is Cdk5, as already discussed ${ }^{45}$. The second is neurofibromin 1, a protein encoded by the tumor suppressor gene NF1 that directly binds to the C-terminus of 5-HT receptor ${ }^{14,57}$. Mutations of the NF1 gene are responsible for neurofibromatosis type 1 (Nf1), a genetic disease characterized by skin pigmentation and benign skin tumors, low-grade tumors of the central and peripheral nervous systems, and learning and attention deficits in some patients. The binding of neurofibromin 1 to $5-\mathrm{HT}_{6}$ receptors strongly enhances native $5 \mathrm{H}^{\mathrm{HT}} 6$ receptor constitutive activity at Gs signaling (Figure 4). Correspondingly, SB 271046, a 5- $\mathrm{H}_{6}$ receptor inverse agonist, decreases cAMP level and downstream signaling in wild-type mice but not $\mathrm{Nf1}^{+/-}$mice ${ }^{57}$. Likewise, blocking $5-\mathrm{HT}_{6}$ receptor/neurofibromin 1 interaction by an interfering peptide strongly reduces $5-\mathrm{HT}_{6}$ receptor constitutive activity in primary neurons. These findings demonstrate that physical interaction between neurofibromin 1 and 5-HT 6 receptor enhances constitutive receptor coupling to $\mathrm{Gs}^{57}$. The third $5-\mathrm{HT}_{6}$ receptor-interacting protein that was found to promote agonist-independent activation of $\mathrm{Gs}$ and cAMP production without altering the agonist-dependent response is G-protein-regulated inducer of neurite outgrowth
1 (GPRIN1) $^{58}$ (Figure 4). The 5-HT 6 receptor-GPRIN1 complex promotes neurite extension and branching in NG108-15 cells and mouse primary neurons through a cAMP- and PKA-dependent mechanism ${ }^{58}$.

Agonist-independent activation of GPCRs by GIPs generally induces more prolonged receptor activation than that elicited by classical agonists. In fact, activation of a GPCR by a GIP will last as long as the protein is bound to the receptor. Accordingly, GIP-dependent GPCR activation can last hours (as shown for mGlu1/5 receptor activation by Homer1a) or even be "permanent", such as 5-HT receptor constitutive activation upon association with neurofibromin 1 . The reversibility of receptor activation will depend only on GIP protein turnover.

\section{Biased agonism at 5- $\mathrm{HT}_{2 \mathrm{~A}}$ receptor: impact of its heteromerization with $\mathrm{mGlu}_{2}$ receptor}

As already discussed, GPCRs transduce signal not only via the activation of one or several G-proteins or its binding to $\beta$-arrestins but also via non-G-protein/non- $\beta$-arrestin pathways. Different ligands of a given GPCR can preferentially stimulate either G-protein- or $\beta$-arrestin-dependent signaling, a phenomenon known as biased signaling ${ }^{59}$. The extreme situation is a ligand displaying no efficacy in promoting

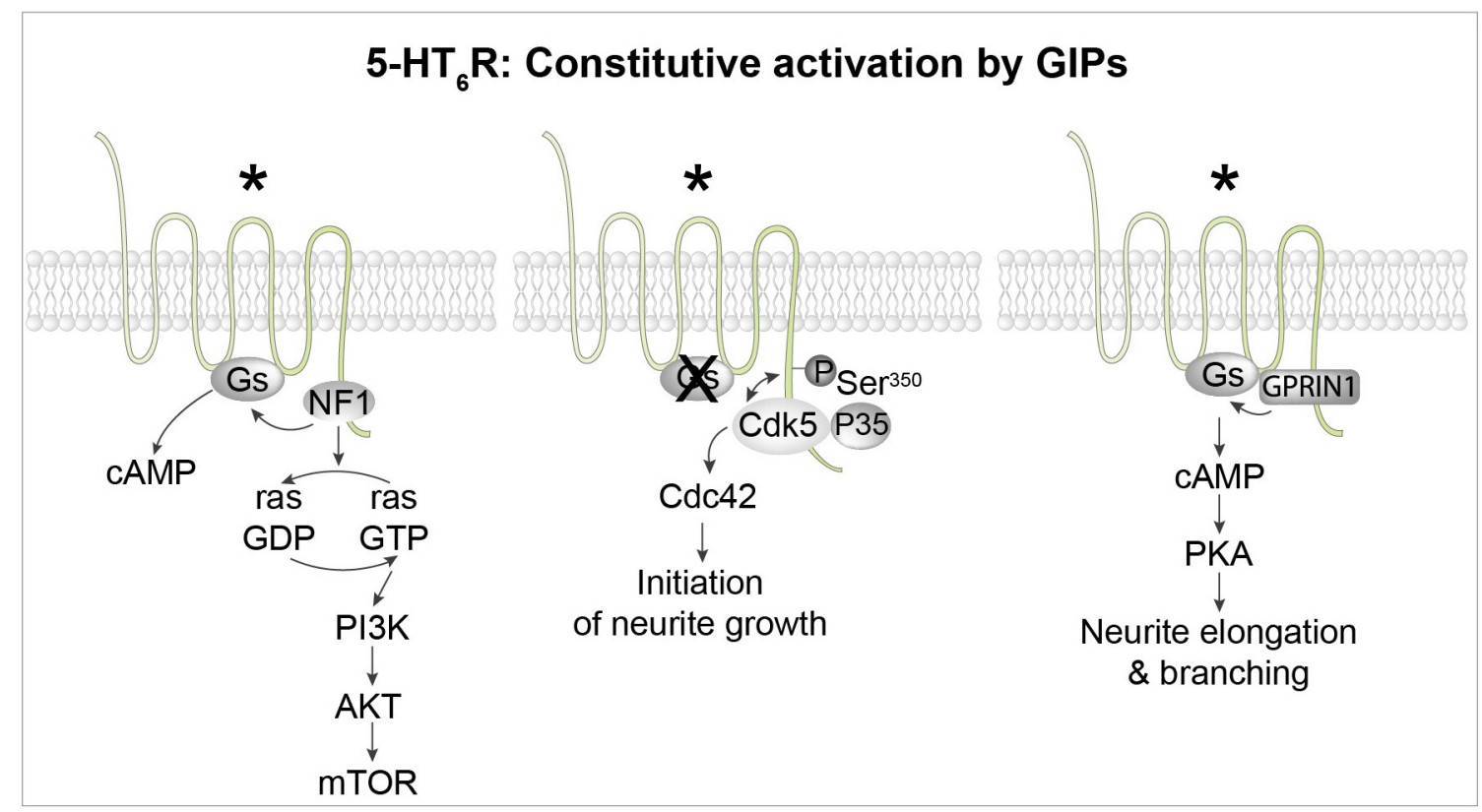

Figure 4. Constitutive activation of $\mathbf{5}-\mathrm{HT}_{6}$ receptors by different GPCR-interacting proteins (GIPs). Left: The 5-HT receptor binds to several proteins of the mammalian target of rapamycin complex 1 (mTORC1) pathway, including mTOR itself and the Ras GTPase-activating protein (Ras-GAP) neurofibromin 1 (NF1). Physical association of NF1 with the receptor strongly enhances constitutive activation of the Gsadenylyl cyclase pathway by the receptor. Middle: The receptor activates the cyclin-dependent kinase 5 (Cdk5)-Cdc42 signaling pathway in an agonist-independent manner to promote the initiation of neurite growth. Dissociation of the 5-HT receptor-Cdk5 complex allows the recruitment of G-protein-regulated inducer of neurite outgrowth 1 (GPRIN1) by the receptor (right panel), which mediates constitutive activation of the Gs-adenylyl cyclase-protein kinase A (PKA) pathway, thereby promoting neurite elongation and branching. ${ }^{*}$ Constitutively active receptor. PI3K, phosphatidylinositol 3-kinase; Ser, serine. 
receptor coupling to G-proteins but serving as an agonist for $\beta$-arrestin-mediated signaling ${ }^{59}$. This phenomenon has been called "biased agonism" or "functional selectivity" quently, depending on the pattern of signaling pathways selected by a given GPCR ligand, cellular and physiological responses will differ. Functional selectivity raised great interest in the pharmaceutical industry with the perspective of developing drugs able to activate signaling pathways underlying therapeutic response but not those responsible for side effects ${ }^{61}$.

As for many GPCRs, biased ligands acting on 5-HT receptors are actively searched in order to obtain more selective drugs with fewer side effects ${ }^{62-65}$. Agonists acting at 5- $\mathrm{HT}_{2 \mathrm{~A}}$ receptors represent one of the most striking illustrations of functional selectivity ${ }^{66,67}$. Some $5-\mathrm{HT}_{2 \mathrm{~A}}$ receptor agonists like lysergic acid diethylamide (LSD), psilocybin ("magic mushrooms" drug), or DOI ("designer drug") trigger hallucinations, whereas its natural ligand 5-HT and other agonists like the anti-parkinsonian compound lisuride or the anti-migraine drug ergotamine do not trigger such psychoactive effects. $5-\mathrm{HT}_{2 \mathrm{~A}}$ receptors are canonically coupled to both the $\mathrm{G} \alpha_{\mathrm{q}}$ protein family and $\beta$-arrestin and quickly desensitized upon 5 -HT stimulation $^{11}$. LSD is a $\beta$-arrestin-biased ligand that promotes preferential $5-\mathrm{HT}_{2 \mathrm{~A}}$ receptor coupling to $\beta$-arrestin compared with 5-HT ${ }^{67}$ (Figure 5). Consistent with these findings, structural studies indicate that the conformation adopted by the structurally related $5-\mathrm{HT}_{2 \mathrm{~B}}$
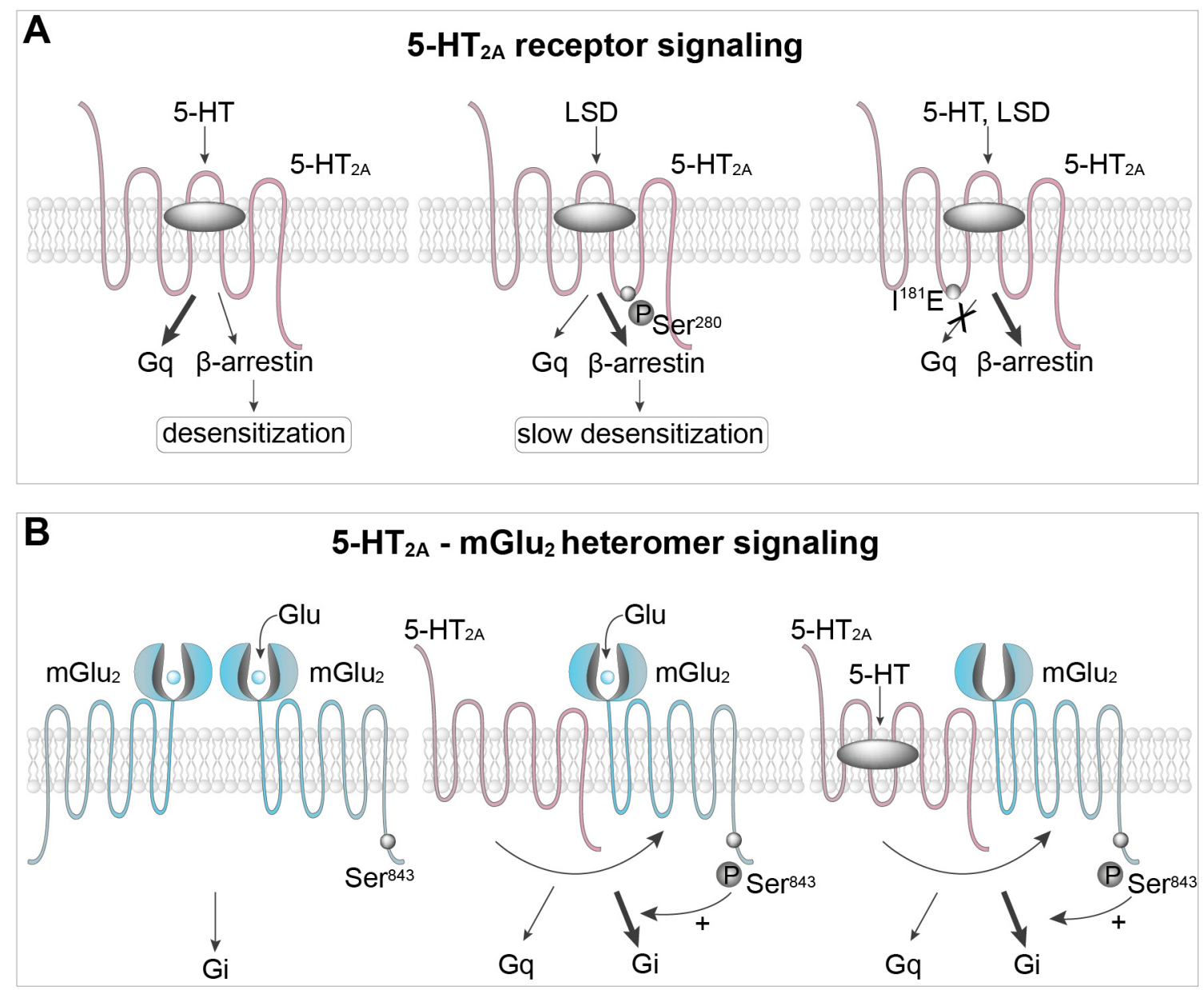

Figure 5. Biased signaling at 5- $\mathrm{HT}_{2 \mathrm{~A}}$ receptors and $\mathbf{5}-\mathrm{HT}_{2 \mathrm{~A}} / \mathrm{mGlu}_{2}$ heteromers. A. $5-\mathrm{HT}_{2 \mathrm{~A}}$ receptor stimulation by $5-\mathrm{HT}$ activates $\mathrm{G} \alpha_{q}$ and to a lesser extent, $\beta$-arrestin signalling and leads to $5-\mathrm{HT}_{2 \mathrm{~A}}$ receptor desensitization. $5-\mathrm{HT}_{2 \mathrm{~A}}$ receptor stimulation by psychedelic hallucinogens such as lysergic acid diethylamide (LSD), but not by non-hallucinogenic agonists, promotes receptor phosphorylation on serine (Ser) ${ }^{280}$, a process reducing receptor desensitization. Binding of the receptor to hallucinogenic agonists also stabilizes conformations favoring $\beta$-arrestin coupling ${ }^{66}$. Substituting isoleucine ${ }^{181}$ of the receptor to glutamate suppresses receptor coupling to $\mathrm{G} \alpha_{\mathrm{a}}$ while potentiating coupling to $\beta$-arrestin upon receptor activation by $5-\mathrm{HT}$ or hallucinogenic agonists. B. Agonist stimulation of metabotropic glutamate receptor 2 (mGlu ${ }_{2}$ ) or $5-\mathrm{HT}_{2 \mathrm{~A}}$ receptor within $\mathrm{mGlu}_{2}-5-\mathrm{HT}_{2 \mathrm{~A}}$ heterodimer promotes mGlu 2 receptor phosphorylation on Ser ${ }^{843}$, which favors engagement of $\mathrm{G} \alpha_{1}$ signaling. 
receptor bound to LSD slightly differs from the conformation elicited by non-hallucinogenic agonists. The most important difference is a more constrained conformation of extracellular loop 2 near the orthosteric site, which causes a more prolonged residence time of LSD, leading to a stronger and more prolonged $\beta$-arrestin recruitment ${ }^{68}$. Recently, a high-resolution structure of hallucinogen-bound $5-\mathrm{HT}_{2 \mathrm{~A}}$ receptor also revealed how hallucinogens stabilize states favoring $\beta$-arrestin coupling ${ }^{67}$. Interestingly, substituting a hydrophobic residue within the intracellular loop 2, essential for coupling of various GPCRs to G-proteins (isoleucine ${ }^{181}$ in $5-\mathrm{HT}_{2 \mathrm{~A}}$ receptor) into glutamate, suppresses receptor coupling to $\mathrm{G} \alpha_{\mathrm{q}}$ while potentiating coupling to $\beta$-arrestin ${ }^{67}$ (Figure 5).

The comparison of phosphoproteomes in 5- $\mathrm{HT}_{2 \mathrm{~A}}$ receptorexpressing recombinant cells challenged with either the hallucinogenic agonist DOI or the non-hallucinogenic agonist lisuride revealed that among thousands of quantified phosphorylated residues, only a few of them are specifically phosphorylated upon exposure to DOI, but not lisuride. These include a serine residue $\left(\mathrm{Ser}^{280}\right.$ ) located in the third intracellular loop of the $5-\mathrm{HT}_{2 \mathrm{~A}}$ receptor itself. The specific phosphorylation of $\operatorname{Ser}^{280}$ upon 5-HT ${ }_{2 \mathrm{~A}}$ receptor stimulation by hallucinogenic agonists was then established in vivo, in mouse prefrontal cortex $^{69}$ (Figure 5). Further functional studies revealed that this biased phosphorylation event is responsible for a reduced desensitization of $5-\mathrm{HT}_{2 \mathrm{~A}}$ receptor when stimulated by hallucinogenic $v s$. non-hallucinogenic agonists ${ }^{69}$. This attenuated $5-\mathrm{HT}_{2 \mathrm{~A}}$ receptor desensitization following stimulation by hallucinogenic agonists results in more sustained receptor activation that might contribute, at least in part, to their psychotropic effects.

The ability of the 5- $\mathrm{HT}_{2 \mathrm{~A}}$ receptor to couple to $\mathrm{G} \alpha_{\mathrm{i}}$ and $\mathrm{G} \alpha_{\mathrm{s}}$ proteins in addition to $\mathrm{G} \alpha_{\mathrm{q}}$ is still controversial ${ }^{67,70}$. An extended analysis by Kim et al. clearly establishes that the $5-\mathrm{HT}_{2 \mathrm{~A}}$ receptor is mostly coupled to the $\mathrm{Gq}$ protein family upon stimulation by either $5-\mathrm{HT}$ or $\mathrm{LSD}^{67}$. 5- $\mathrm{HT}_{2 \mathrm{~A}}$ receptors can form heteromers with the $\mathrm{mGlu}_{2}$ receptor, a Go $\alpha_{i}$ protein-coupled receptor $^{71}$ (Figure 5). Within the heteromer, the respective coupling of each protomer to its cognate G-protein is oppositely influenced by the other protomer: while $5-\mathrm{HT}_{2 \mathrm{~A}}$ receptor coupling to $\mathrm{G} \alpha_{\mathrm{q}}$ in response to agonist stimulation is decreased by approximately $50 \%$ within heteromers, compared with $5-\mathrm{HT}_{2 \mathrm{~A}}$ receptor not associated with $\mathrm{mGlu}_{2}$ receptor, $\mathrm{G} \alpha_{\mathrm{i}}$ activation elicited by agonist stimulation of the $\mathrm{mGlu}_{2}$ receptor is strongly potentiated by its heteromerization with the $5-\mathrm{HT}_{2 \mathrm{~A}}$ receptor $^{72}$. A recent study revealed that the $5-\mathrm{HT}_{2 \mathrm{~A}}$ receptor also affects $\mathrm{mGlu}_{2}$ receptor trafficking and subcellular localization through a mechanism dependent on their heterodimerization ${ }^{73}$.

We demonstrated that $5-\mathrm{HT}_{2 \mathrm{~A}}$ receptor co-expression is required for the phosphorylation of the $\mathrm{mGlu}_{2}$ receptor on a serine located in its C-terminal domain $\left(\mathrm{Ser}^{843}\right)$ upon $\mathrm{mGlu}_{2}$ receptor stimulation by the orthosteric agonist LY379268 in recombinant cells $^{74}$. Furthermore, phosphorylation of $\mathrm{Ser}^{843}$ elicited by $\mathrm{mGlu}_{2}$ receptor stimulation is blocked by a $5-\mathrm{HT}_{2 \mathrm{~A}}$ receptor antagonist (Figure 5). Corroborating these observations in cell cultures, in vivo administration of LY379268 increases $\mathrm{mGlu}_{2}$ receptor phosphorylation at $\mathrm{Ser}^{843}$ in prefrontal cortex of wild-type mice but not $5-\mathrm{HT}_{2 \mathrm{~A}}{ }^{-1-}$ mice. Stimulation of the $5-\mathrm{HT}_{2 \mathrm{~A}}$ receptor also increases phosphorylation of $\mathrm{Ser}^{843}$, an effect blocked by $\mathrm{mGlu}_{2}$ receptor antagonist, thus highlighting a sophisticated crosstalk between both receptors to promote $\mathrm{mGlu}_{2} \mathrm{Ser}^{843}$ phosphorylation (Figure 5). Mutation of $\mathrm{Ser}^{843}$ into alanine strongly reduces $\mathrm{G \alpha}_{\mathrm{i} / \mathrm{o}}$ signaling elicited by $\mathrm{mGlu}_{2}$ or $5-\mathrm{HT}_{2 \mathrm{~A}}$ receptor stimulation in cells co-expressing both receptors ${ }^{74}$. This identifies $\mathrm{mGlu}_{2} \mathrm{Ser}^{843}$ phosphorylation as a mechanism by which the $5-\mathrm{HT}_{2 \mathrm{~A}}$ receptor can "hijack" $\mathrm{G} \alpha_{\mathrm{i}}$ signaling within $5-\mathrm{HT}_{2 \mathrm{~A}}-\mathrm{mGlu}_{2}$ heteromers. It has been proposed that the balance of $\mathrm{G \alpha}_{\mathrm{q}} v s$. $\mathrm{G \alpha}_{\mathrm{i}}$ signaling at $5-\mathrm{HT}_{2 \mathrm{~A}}-\mathrm{mGlu}_{2}$ heteromers determines pro-psychotic $v s$. antipsychotic activity of ligands of each of these receptors ${ }^{72}$. Given the critical influence of $\mathrm{Ser}^{843}$ phosphorylation on $\mathrm{G}_{\mathrm{i} / \mathrm{o}}$ signaling at $5-\mathrm{HT}_{2 \mathrm{~A}}-\mathrm{mGlu}_{2}$ heteromers, alterations of its phosphorylation level might be a key event underlying the pathogenesis of psychotic disorders such as schizophrenia as well as the behavioral effects of psychedelic drugs and antipsychotics.

\section{5-HT receptor spatiotemporal signaling}

GPCR signal transduction is not stable over time, even in the presence of constant agonist stimulation. In addition, it depends on receptor subcellular localization. Most GPCRs undergo desensitization upon agonist stimulation, leading to a decline of G-protein-dependent signaling while alternative pathways, such as the $\beta$-arrestin-dependent pathway, are enhanced $^{9,75,76}$. Many GPCRs are internalized in endosomes upon prolonged agonist stimulation. Surprisingly, some GPCRs continue to transduce signal in endosomes, not only via $\beta$-arrestin but also, in some cases, via G-proteins ${ }^{76,77}$. For instance, parathormone $(\mathrm{PTH})$ receptors still activate $\mathrm{G}_{\mathrm{s}}$ and cAMP production in endosomes ${ }^{76}$.

We have recently described another example of time-dependent sequential coupling. As previously discussed, 5- $\mathrm{HT}_{6}$ receptors constitutively activate the $\mathrm{Cdk} 5-\mathrm{Cdc} 42$ pathway to stimulate the initiation of neurite outgrowth, and the Gs-AC pathway, via GPRIN1 physically associated with the receptor, to promote neurite extension and branching ${ }^{45,58}$. However, these two different signaling pathways are not concomitantly activated (Figure 6A). During early neuronal differentiation, Cdk5, but not GPRIN1, binds to the 5-HT 6 receptor and the Cdc42 signaling pathway is switched "on" 58 (Figure 6A). Subsequently, $\mathrm{Cdk} 5$ is released from 5 - $\mathrm{HT}_{6}$ receptors, allowing recruitment of GPRIN1, activation of the Gs-AC pathway, cAMP production, and neurite extension and branching ${ }^{58}$ (Figure 6A).

5-HT $\mathrm{HA}_{1 \mathrm{~A}}$ receptors are particularly interesting to illustrate the impact of subcellular localization of GPCRs on their signaling specificity (Figures 6B, C). 5- $\mathrm{HT}_{1 \mathrm{~A}}$ autoreceptors are localized 

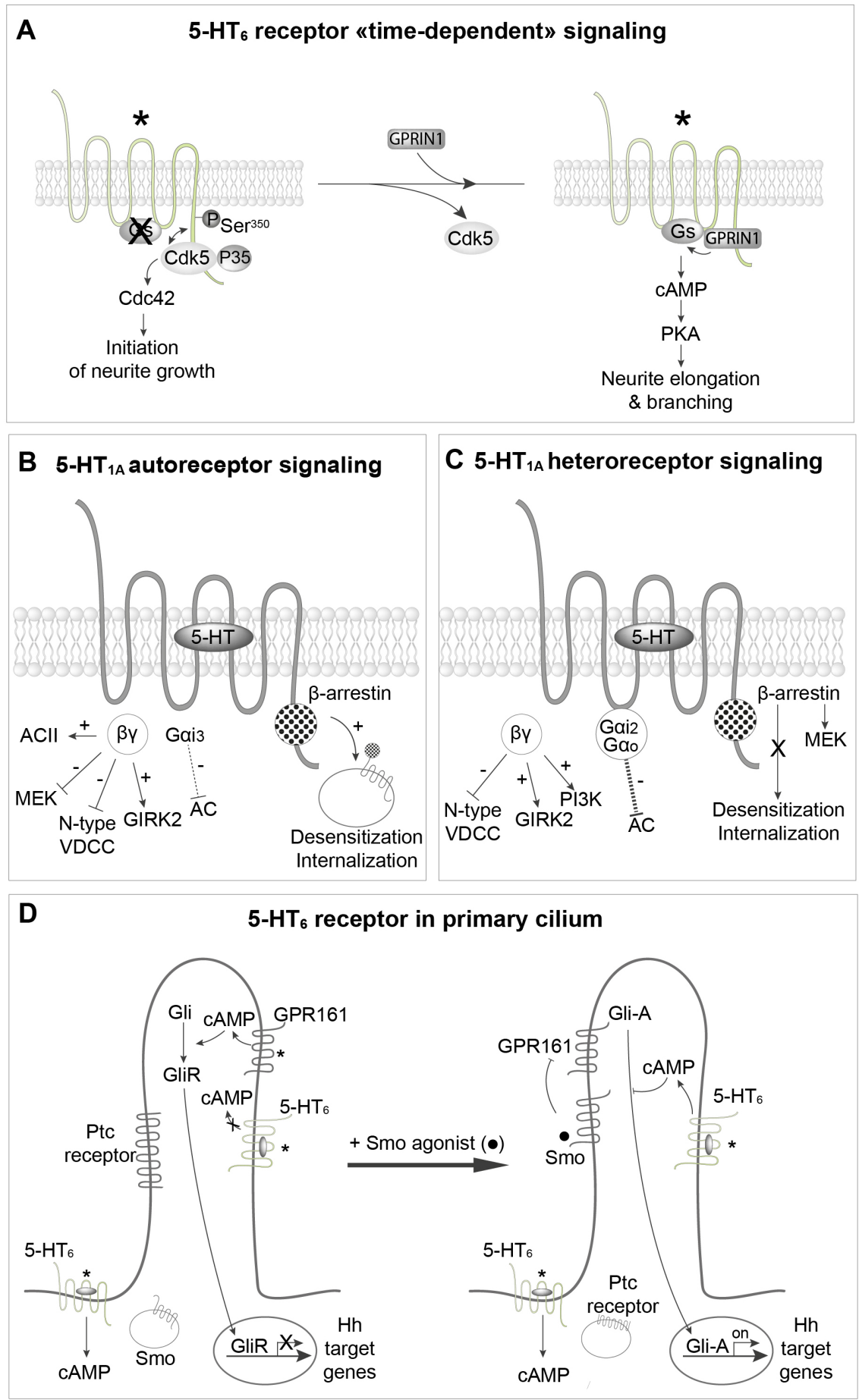

Figure 6. Spatiotemporal regulation of 5-HT receptor signaling. A. Sequential engagement cyclin-dependent kinase 5 (Cdk5)-Cdc42 and Gs-adenylyl cyclase pathways by constitutively active $5-\mathrm{HT}_{6}$ receptors during neuronal differentiation and dendritic tree morphogenesis. B.C. Difference in coupling properties of $5-\mathrm{HT}_{1 \mathrm{~A}}$ autoreceptor and heteroreceptors and in their propensity to desensitize and internalize upon agonist stimulation. D. Spatiotemporal regulation of $5-\mathrm{HT}_{6}$ receptor coupling to $\mathrm{Gs}$ in neurons. 5- $\mathrm{HT}_{6}$ receptors located in the soma, but not receptors located in the primary cilium, activate cAMP production (in absence or presence of agonist). Upon agonist stimulation, Smoothened (Smo) enters the cilium and inhibits cAMP production by constitutively active GPR161. This favors translocation of active Gli transcription factor (Gli-A) to the nucleus and the transcription of Hedgehog (Hh)-regulated genes. Concomitantly, 5-HT receptors located in the primary cilium become able to activate local cAMP production, which might exert a feedback inhibition of Gli-A. *Constitutively active receptors. AC, adenylyl cyclase; GIRK2, G-protein-gated inwardly rectifying potassium channel 2; GPRIN1, G-protein-regulated inducer of neurite outgrowth 1; PI3K, phosphatidylinositol 3-kinase; PKA, protein kinase A; Ptc, patched; Ser, serine; VDCC, voltage-dependent calcium channel. 
on 5-HT neurons on both cell bodies (in Raphe nucleus) and pre-synaptic terminals, whereas $5-\mathrm{HT}_{1 \mathrm{~A}}$ heteroreceptors are localized post-synaptically on target neurons ${ }^{13}$. It is now well established that their signaling pathways are different ${ }^{13,78}$. 5- $\mathrm{HT}_{1 \mathrm{~A}}$ autoreceptors are coupled to $\mathrm{G \alpha}_{\mathrm{i} 3}$, whereas hippocampal heteroreceptors are coupled to $\mathrm{G \alpha}_{\mathrm{i} 2}$ and $\mathrm{G \alpha}_{\mathrm{o}}{ }^{78}$. There is a consensus on the capacity of $5-\mathrm{HT}_{1 \mathrm{~A}}$ receptor agonists to inhibit forskolin-stimulated $\mathrm{AC}$ in hippocampal membranes, whereas such an inhibition seems to depend on the agonist used in Raphe nucleus membranes ${ }^{78}$. It is likely that the presence in the Raphe nucleus of AC type II, which is known to be stimulated by $\beta \gamma$ released from activated $G \alpha$, masks inhibition of AC by $5-\mathrm{HT}_{1 \mathrm{~A}}$ autoreceptors ${ }^{78}$.

5-HT $\mathrm{TA}_{1 \mathrm{~A}}$ autoreceptors and heteroreceptors inhibit and stimulate the Erk1,2 pathway, respectively, while in the presence of mitogen $\mathrm{FGF}_{2}$ receptors, 5- $\mathrm{HT}_{1 \mathrm{~A}}$ autoreceptors also stimulate the Erk1,2 pathway (Figures 6B, C). Autoreceptors and heteroreceptors also differ in their ability to desensitize. Administration of the $5-\mathrm{HT}_{1 \mathrm{~A}}$ receptor agonist $8-\mathrm{OH}$ DPAT as well as prolonged stimulation (10-15 days) of 5-HT ${ }_{1 \mathrm{~A}}$ autoreceptors elicited by fluoxetine or other specific serotonin reuptake inhibitors (SSRIs) result in desensitization and downregulation of 5-HT $\mathrm{H}_{1 \mathrm{~A}}$ autoreceptors, whereas heteroreceptors do not desensitize $\mathrm{s}^{78,79}$. The reason for this difference is unknown. $5-\mathrm{HT}_{1 \mathrm{~A}}$ autoreceptors inhibit presynaptic 5-HT release. Since the kinetics of autoreceptor desensitization, observed following the administration of SSRIs is similar to that of their antidepressant effects, it has been suggested that desensitization of autoreceptors is mandatory to have sufficient 5-HT within the synapse to fully activate heteroreceptors ${ }^{13}$. Other fine differences between 5- $\mathrm{HT}_{1 \mathrm{~A}}$ autoreceptor and heteroreceptor signaling have been recently reviewed ${ }^{78}$.

The 5- $\mathrm{HT}_{6}$ receptor represents another intriguing example of the influence of subcellular compartmentation on 5-HT receptor signal transduction. In neurons, 5- $\mathrm{HT}_{6}$ receptors are mainly located in the primary cilium, but they are also present at the plasma membrane of the cell body ${ }^{58}$ (Figure 6D). GPRIN1, which increases 5- $\mathrm{HT}_{6}$ receptor coupling to $\mathrm{G}_{\mathrm{s}}$, is co-localized with the receptor in the cell body but not in the primary cilium $^{58}$. Interestingly, 5- $\mathrm{HT}_{6}$ receptors stimulate cAMP production in the cell body but not in the primary cilium under basal conditions ${ }^{80}$. The more probable explanation is that coupling of $5-\mathrm{HT}_{6}$ receptors to $\mathrm{G}_{\mathrm{s}}$ is inhibited in the primary cilium by either a GIP or a post-translational modification, such as phosphorylation. However, no data supporting these hypotheses are so far available. In fact, a recent study suggests that $5-\mathrm{HT}_{6}$ receptor-operated Gs signaling in the primary cilium can be finely regulated by a complex sequence of events depending on other ciliary receptors. When smoothened (Smo) receptor, a GPCR central in Hedgehog (Hh) signaling thought to decrease cAMP in the primary cilium through $\mathrm{G} \alpha_{i}$, is stimulated by an agonist, it enters the cilium (Figure 6D). The $\mathrm{Hh}$ patched (Ptc) receptor is internalized and the constitutively active Gs-coupled receptor GPR161 is inhibited. This allows activation of the Gli transcription factor (Gli-A), which translocates into the nucleus, where it induces the transcription of Hh-regulated genes ${ }^{81}$. 5-HT 6 receptors concomitantly become able to activate cAMP production upon agonist receptor stimulation or as a consequence of constitutive activity, likely because they couple to $G_{s}$, even though this remains to be demonstrated. Though much work remains to be done to understand the mechanism involved, these findings indicate a fine temporal regulation of $5-\mathrm{HT}_{6}$ receptor-operated signaling in the primary cilium. Jiang et al. also proposed that the local production of cAMP elicited by $5-\mathrm{HT}_{6}$ receptors in the cilium exerts a local feedback inhibition of Gli-A ${ }^{80}$ (Figure 6D).

\section{Conclusions and future directions}

5-HT receptor signaling is not a closed chapter of pharmacology, and several important lines of research are still very active. One of them is the relationship between 5-HT receptor 3D structure and signaling. How many activated or inactivated conformations 5-HT receptors can adopt, what structural determinants are required for their alternative coupling to G-proteins, $\beta$-arrestins, and other signal transduction molecules, how biased agonists favor some of them, and how dimerization or heterodimerization influences signaling of 5-HT receptors, as established for the $5-\mathrm{HT}_{2 \mathrm{~A}}-\mathrm{mGlu}_{2}$ heterocomplex, remain important open questions that certainly warrant further exploration ${ }^{71,72,74}$. Some clues concerning the structural determinants in the $5-\mathrm{HT}_{2 \mathrm{~A}}$ receptor required for hallucinogen biased actions have recently been revealed ${ }^{67-69}$. Likewise, characterizing the constitutively active conformations selected upon interactions of the $5-\mathrm{HT}_{6}$ receptor with GIPs such as neurofibromin 1, Cdk5, and GPRIN1 might be of utmost interest given the potential of this receptor as a therapeutic target for the treatment of cognitive deficits associated with neurodevelopmental disorders and dementia ${ }^{45,58}$. Another important line of future research concerns the spatiotemporal regulation of signaling engaged by 5-HT receptors, such as the one found for the $5-\mathrm{HT}_{6}$ receptor ${ }^{80}$.

Another avenue of research is serotonylation ${ }^{2-4}$, which has a key influence on the physiology of peripheral cells, such as platelets, pancreatic $\beta$-cells, and smooth muscle cells. Surprisingly little is known about the regulation of 5-HT neuron functional activity by this biochemical process, which has long been underestimated. It is likely that the pathophysiological influence of epigenetic mechanisms related to serotonylation will also rapidly emerge in the fields of neurology and psychiatry $^{6,7}$. 
1. Azmitia E: Functional anatomy of the serotonergic system. In: Müller $\mathrm{CaC}, \mathrm{KA}$, editor. Handbook of Behavioral neurobiology of Serotonin. London: Academic Press, Elsevier; 2020.

Reference Source

2. Walther DJ, Peter JU, Winter S, et al.: Serotonylation of small GTPases is a signal transduction pathway that triggers platelet alpha-granule release. Cell. 2003; 115(7): 851-62.

PubMed Abstract | Publisher Full Text | Faculty Opinions Recommendation

3. Bader M: Serotonylation: Serotonin Signaling and Epigenetics. Front Mol Neurosci. 2019; 12: 288

PubMed Abstract | Publisher Full Text | Free Full Text |

Faculty Opinions Recommendation

4. CFarrelly LA, Thompson RE, Zhao S, et al:: Histone serotonylation is a permissive modification that enhances TFIID binding to H3K4me3. Nature. 2019; 567(7749): 535-9.

PubMed Abstract | Publisher Full Text | Free Full Text |

Faculty Opinions Recommendation

5. Muma NA, Mi Z: Serotonylation and Transamidation of Other Monoamines. ACS Chem Neurosci. 2015; 6(7): 961-9.

PubMed Abstract | Publisher Full Text

6. Girault JA: Epigenetic tinkering with neurotransmitters. Science. 2020; 368(6487): 134-5.

PubMed Abstract | Publisher Full Text

7. Lepack EA, Werner CT, Stewart AF, et al:: Dopaminylation of histone $\mathrm{H}_{3}$ in ventral tegmental area regulates cocaine seeking. Science. 2020; 368(6487): 197-201.

PubMed Abstract | Publisher Full Text | Free Full Text

8. Jacob F: Evolution and tinkering. Science. 1977; 196(4295): 1161-6. PubMed Abstract | Publisher Full Text

9. Bockaert J, Pin JP: Molecular tinkering of G protein-coupled receptors: An evolutionary success. EMBO J. 1999; 18(7): 1723-9. PubMed Abstract | Publisher Full Text | Free Full Text

10. Liu Z, Zhou Z, Zhang Y, et al:: Ocean acidification inhibits initial shell formation of oyster larvae by suppressing the biosynthesis of serotonin and dopamine. Sci Total Environ. 2020; 735: 139469. PubMed Abstract | Publisher Full Text | Faculty Opinions Recommendation

11. Marin $\mathrm{P}$, Becamel $\mathrm{C}$, Chaumont-Dubel $\mathrm{S}$, et al:: Classification and signaling characteristics of 5-HT receptors: toward the concept of 5-HT receptosomes. In: MÜLLER CAJ, BL, editor. Handbook of Behavioral neurobiology of Serotonin. London: Academic Press; 2020; 31: 91-120. Publisher Full Text

12. Bockaert J, Claeysen S, Bécamel C, et al:: Neuronal 5-HT metabotropic receptors: Fine-tuning of their structure, signaling, and roles in synaptic modulation. Cell Tissue Res. 2006; 326(2): 553-72. PubMed Abstract | Publisher Full Text

13. Sharp T, Barnes NM: Central 5-HT receptors and their function; present and future. Neuropharmacology. 2020; 177: 108155. PubMed Abstract | Publisher Full Text | Faculty Opinions Recommendation

14. Chaumont-Dubel S, Dupuy V, Bockaert J, et al:: The $5-\mathrm{HT}$ receptor interactome: New insight in receptor signaling and its impact on brain physiology and pathologies. Neuropharmacology. 2020; 172: 107839. PubMed Abstract | Publisher Full Text

15. Marin $\mathrm{P}$, Becamel $\mathrm{C}$, Dumuis A, et al:: 5-HT receptor-associated protein networks: New targets for drug discovery in psychiatric disorders? Curr Drug Targets. 2012; 13(1): 28-52.

PubMed Abstract | Publisher Full Text

16. Wirth $\mathrm{A}$, Holst $\mathrm{K}$, Ponimaskin $\mathrm{E}$ : How serotonin receptors regulate morphogenic signalling in neurons. Prog Neurobiol. 2017; 151: 35-56. PubMed Abstract | Publisher Full Text

17. De Deurwaerdère $P$, Bharatiya $R$, Chagraoui $A$, et al.: Constitutive activity of 5-HT receptors: Factual analysis. Neuropharmacology. 2020; 168: 107967. PubMed Abstract | Publisher Full Text | Faculty Opinions Recommendation

18. Dale GL, Friese $P$, Batar $P$, et al:: Stimulated platelets use serotonin to enhance their retention of procoagulant proteins on the cell surface. Nature. 2002; 415(6868): 175-9.

PubMed Abstract | Publisher Full Text

19. Pisano JJ, Finlayson JS, Peyton MP, et al.: Epsilon-(gamma glutamyl) lysine in fibrin: Lack of crosslink formation in Factor 13 deficiency. Proc Natl Acad Sci U S A. 1971; 68(4): 770-2.

PubMed Abstract | Publisher Full Text | Free Full Text

20. Aktories K: Bacterial protein toxins that modify host regulatory GTPases. Nat Rev Microbiol. 2011; 9(7): 487-98.

PubMed Abstract | Publisher Full Text
21. Walther DJ, Stahlberg S, Vowinckel J: Novel roles for biogenic monoamines: From monoamines in transglutaminase-mediated post-translational protein modification to monoaminylation deregulation diseases. FEBS J. 2011; 278(24): 4740-55.

PubMed Abstract | Publisher Full Text

22. Wang HM, Wang $\mathrm{Y}$, Liu M, et al:: Fluoxetine inhibits monocrotaline-induced pulmonary arterial remodeling involved in inhibition of RhoA-Rho kinase and Akt signalling pathways in rats. Can J Physiol Pharmacol. 2012; 90(11): 1506-15. PubMed Abstract | Publisher Full Text

23. CGuilluy C, Eddahibi S, Agard C, et al:: RhoA and Rho kinase activation in human pulmonary hypertension: Role of 5-HT signaling. Am J Respir Crit Care Med. 2009; 179(12): 1151-8.

PubMed Abstract | Publisher Full Text | Faculty Opinions Recommendation

24. Watts SW, Priestley JRC, Thompson JM: Serotonylation of vascular proteins important to contraction. PLOS One. 2009; 4(5): e5682. PubMed Abstract | Publisher Full Text | Free Full Text

25. Penumatsa KC, Fanburg BL: Transglutaminase 2-mediated serotonylation in pulmonary hypertension. Am J Physiol Lung Cell Mol Physiol. 2014; 306(4): L309-15.

PubMed Abstract | Publisher Full Text | Free Full Text

26. Ayme-Dietrich E, Lawson R, Da-Silva S, et al:: Serotonin contribution to cardiac valve degeneration: New insights for novel therapies? Pharmacol Res. 2019; 140: 33-42.

PubMed Abstract | Publisher Full Text | Faculty Opinions Recommendation

27. Paulmann N, Grohmann M, Voigt JP, et al.: Intracellular serotonin modulates insulin secretion from pancreatic beta-cells by protein serotonylation. PLOS Biol. 2009; 7(10): e1000229.

PubMed Abstract | Publisher Full Text | Free Full Text |

Faculty Opinions Recommendation

28. Mi Z, Si T, Kapadia K, et al.: Receptor-stimulated transamidation induces activation of Rac1 and Cdc42 and the regulation of dendritic spines. Neuropharmacology. 2017; 117: 93-105. PubMed Abstract | Publisher Full Text | Free Full Text

29. Hummerich R, Thumfart JO, Findeisen $P$, et al:: Transglutaminase-mediated transamidation of serotonin, dopamine and noradrenaline to fibronectin: Evidence for a general mechanism of monoaminylation. FEBS Lett. 2012; 586(19): 3421-8.

PubMed Abstract | Publisher Full Text

30. Colgan LA, Putzier I, Levitan ES: Activity-dependent vesicular monoamine transporter-mediated depletion of the nucleus supports somatic release by serotonin neurons. J Neurosci. 2009; 29(50): 15878-87. PubMed Abstract | Publisher Full Text | Free Full Text

31. Young AB, Pert CD, Brown DG, et al:: Nuclear localization of histamine in neonatal rat brain. Science. 1971; 173(3993): 247-9.

PubMed Abstract | Publisher Full Text

32. Gerace L, Burke B: Functional organization of the nuclear envelope. Annu Rev Cell Biol. 1988; 4: 335-74.

PubMed Abstract | Publisher Full Text

33. Nygaard R, Zou $\mathrm{Y}$, Dror RO, et al:: The dynamic process of $\beta_{2}$-adrenergic receptor activation. Cell. 2013; 152(3): 532-42.

PubMed Abstract | Publisher Full Text | Free Full Text |

Faculty Opinions Recommendation

34. D Du Y, Duc NM, Rasmussen SGF, et al.: Assembly of a GPCR-G Protein Complex. Cell. 2019; 177(5): 1232-1242.e11. PubMed Abstract | Publisher Full Text | Free Full Text Faculty Opinions Recommendation

35. Suomivuori CM, Latorraca NR, Wingler LM, et al.: Molecular mechanism of biased signaling in a prototypical G protein-coupled receptor. Science. 2020 367(6480): 881-7.

PubMed Abstract | Publisher Full Text | Free Full Text |

Faculty Opinions Recommendation

36. DeWire SM, Ahn S, Lefkowitz RJ, et al.: Beta-arrestins and cell signaling. Annu Rev Physiol. 2007; 69: 483-510.

PubMed Abstract | Publisher Full Text

37. Labasque M, Reiter E, Becamel C, et al.: Physical interaction of calmodulin with the 5-hydroxytryptamine ${ }_{2 C}$ receptor $C$-terminus is essential for $G$ proteinindependent, arrestin-dependent receptor signaling. Mol Biol Cell. 2008; 19(11): 4640-50.

PubMed Abstract | Publisher Full Text | Free Full Text

38. Wu N, Hanson SM, Francis DJ, et al.: Arrestin binding to calmodulin: A direct interaction between two ubiquitous signaling proteins. $J$ Mol Biol. 2006; 364(5): 955-63.

PubMed Abstract | Publisher Full Text | Free Full Text 
39. Lafitte D, Heck AJ, Hill TJ, et al.: Evidence of noncovalent dimerization of calmodulin. Eur J Biochem. 1999; 261(1): 337-44. PubMed Abstract | Publisher Full Text

40. Barthet G, Framery B, Gaven F, et al:: 5-hydroxytryptamine 4 receptor activation of the extracellular signal-regulated kinase pathway depends on Src activation but not on G protein or beta-arrestin signaling. Mol Biol Cell. 2007; 18(6): 1979-91.

PubMed Abstract | Publisher Full Text | Free Full Text

41. Gill RK, Saksena S, Tyagi S, et al:: Serotonin inhibits $\mathrm{Na}+\mathbf{H}+$ exchange activity via 5-HT4 receptors and activation of PKC alpha in human intestinal epithelia cells. Gastroenterology. 2005; 128(4): 962-74. PubMed Abstract | Publisher Full Text

42. Cochet M, Donneger R, Cassier E, et al:: 5-HT4 receptors constitutively promote the non-amyloidogenic pathway of APP cleavage and interact with ADAM10. ACS Chem Neurosci. 2013; 4(1): 130-40. PubMed Abstract | Publisher Full Text | Free Full Text

43. Baranger K, Giannoni P, Girard SD, et al:: Chronic treatments with a 5-HT receptor agonist decrease amyloid pathology in the entorhinal cortex and learning and memory deficits in the 5xFAD mouse model of Alzheimer's disease. Neuropharmacology. 2017; 126: 128-41.

PubMed Abstract | Publisher Full Text

44. Rochais C, Lecoutey C, Hamidouche $\mathrm{K}$, et al:: Donecopride, a Swiss army knife with potential against Alzheimer's disease. Br J Pharmacol. 2020; 177(9): 1988-2005.

PubMed Abstract | Publisher Full Text | Free Full Text

45. Duhr $F$, Déléris $P$, Raynaud $F$, et al:: Cdk5 induces constitutive activation of 5-HT6 receptors to promote neurite growth. Nat Chem Biol. 2014; 10(7): 590-7. PubMed Abstract | Publisher Full Text

46. Jacobshagen $M$, Niquille $M$, Chaumont-Dubel S, et al.: The serotonin 6 receptor controls neuronal migration during corticogenesis via a ligand-independent Cdk5-dependent mechanism. Development. 2014; 141(17): 3370-7. PubMed Abstract | Publisher Full Text | Free Full Text

47. Dayer AG, Jacobshagen M, Chaumont-Dubel S, et al:: 5-HT6 Receptor: A New Player Controlling the Development of Neural Circuits. ACS Chem Neurosci. 2015; 6(7): 951-60.

PubMed Abstract | Publisher Full Text

48. Labus J, Röhrs KF, Ackmann J, et al:: Amelioration of Tau pathology and memory deficits by targeting 5-HT7 receptor. Prog Neurobiol. 2021; 197 memory 101900.

PubMed Abstract | Publisher Full Text

49. Ango F, Prézeau L, Muller T, et al:: Agonist-independent activation of metabotropic glutamate receptors by the intracellular protein Homer. Nature. 2001; 411(6840): 962-5.

PubMed Abstract | Publisher Full Text

50. Chokshi V, Gao M, Grier BD, et al.: Input-Specific Metaplasticity in the Visual Cortex Requires Homer1a-Mediated mGluR5 Signaling. Neuron. 2019; 104(4): 736-748.e6.

PubMed Abstract | Publisher Full Text | Free Full Text | Faculty Opinions Recommendation

51. Marton TM, Hussain Shuler MG, Worley PF: Homer 1a and mGluR5 phosphorylation in reward-sensitive metaplasticity: A hypothesis of neurona selection and bidirectional synaptic plasticity. Brain Res. 2015; 1628(Pt A): $17-28$.

PubMed Abstract | Publisher Full Text

52. Holz A, Mülsch F, Schwarz MK, et al.: Enhanced mGlu5 Signaling in Excitatory Neurons Promotes Rapid Antidepressant Effects via AMPA Receptor Activation. Neuron. 2019; 104(2): 338-352.e7. PubMed Abstract | Publisher Full Text | Faculty Opinions Recommendation

53. Hu JH, Park JM, Park S, et al:: Homeostatic scaling requires group I mGluR activation mediated by Homer1a. Neuron. 2010; 68(6): 1128-42. PubMed Abstract | Publisher Full Text | Free Full Text

54. Diering GH, Nirujogi RS, Roth RH, et al:: Homer1a drives homeostatic scaling-down of excitatory synapses during sleep. Science. 2017; 355(6324): $511-5$.

PubMed Abstract | Publisher Full Text | Free Full Text | Faculty Opinions Recommendation

55. Meffre J, Chaumont-Dubel S, Mannoury La Cour C, et al:: 5-HT(6) receptor recruitment of $m T O R$ as a mechanism for perturbed cognition in schizophrenia. EMBO Mol Med. 2012; 4(10): 1043-56. PubMed Abstract | Publisher Full Text | Free Full Text

56. Berthoux C, Hamieh AM, Rogliardo A, et al.: Early 5-HT ${ }_{6}$ receptor blockade prevents symptom onset in a model of adolescent cannabis abuse. EMBO MO Med. 2020; 12(5): e10605.

PubMed Abstract | Publisher Full Text | Free Full Text

57. Deraredj Nadim W, Chaumont-Dubel S, Madouri $F$, et al: Physical interaction between neurofibromin and serotonin 5-HT6 receptor promotes receptor constitutive activity. Proc Natl Acad Sci U S A. 2016; 113(43): 12310-5. PubMed Abstract | Publisher Full Text | Free Full Text
58. Pujol CN, Dupuy V, Séveno M, et al:: Dynamic interactions of the 5-HT ${ }_{6}$ receptor with protein partners control dendritic tree morphogenesis. Sci Signal. 2020; 13(618): eaax9520.

PubMed Abstract | Publisher Full Text

59. Azzi M, Charest PG, Angers S, et al: Beta-arrestin-mediated activation of MAPK by inverse agonists reveals distinct active conformations for $G$ proteincoupled receptors. Proc Natl Acad Sci U S A. 2003; 100(20): 11406-11. PubMed Abstract | Publisher Full Text | Free Full Text Faculty Opinions Recommendation

60. Costa-Neto CM, Parreiras-E-Silva LT, Bouvier M: A Pluridimensional View of Biased Agonism. Mol Pharmacol. 2016; 90(5): 587-95. PubMed Abstract | Publisher Full Text | Faculty Opinions Recommendation

61. - Smith JS, Lefkowitz RJ, Rajagopal S: Biased signalling: From simple switches to allosteric microprocessors. Nat Rev Drug Discov. 2018; 17(4): 243-60.

PubMed Abstract | Publisher Full Text | Free Full Text |

Faculty Opinions Recommendation

62. S Sniecikowska J, Gluch-Lutwin M, Bucki A, et al.: Discovery of Novel pERK1/2or $\beta$-Arrestin-Preferring 5-HT $1 \mathrm{~A}$ Receptor-Biased Agonists: Diversified Therapeutic-like versus Side Effect Profile. J Med Chem. 2020; 63(19): 10946-71.

PubMed Abstract | Publisher Full Text | Free Full Text |

Faculty Opinions Recommendation

63. $\mathrm{Kim} Y, \mathrm{Kim} H$, Lee J, et al.: Discovery of $\beta$-Arrestin Biased Ligands of 5HT R. J Med Chem. 2018; 61(16): 7218-33. PubMed Abstract | Publisher Full Text | Faculty Opinions Recommendation

64. Gaven F, Pellissier LP, Queffeulou E, et al:: Pharmacological profile of engineered $5-\mathrm{HT}_{4}$ receptors and identification of $5-\mathrm{HT}_{4}$ receptor-biased ligands. Brain Res. 2013; 1511: 65-72. PubMed Abstract | Publisher Full Text

65. Vidal B, Bolbos R, Redouté J, et al.: Pharmacological MRI to investigate the functional selectivity of $5-\mathrm{HT}_{1 \mathrm{~A}}$ receptor biased agonists. Neuropharmacology. 2020; 172: 107867.

PubMed Abstract | Publisher Full Text | Faculty Opinions Recommendation

66. P Poulie CBM, Jensen AA, Halberstadt AL, et al.: DARK Classics in Chemical Neuroscience: NBOMes. ACS Chem Neurosci. 2019. PubMed Abstract | Publisher Full Text | Faculty Opinions Recommendation

67. Nim K, Che T, Panova O, et al:: Structure of a Hallucinogen-Activated GqCoupled 5-HT 2 Serotonin Receptor. Cell. 2020; 182(6): 1574-1588.e19. PubMed Abstract | Publisher Full Text | Free Full Text | Faculty Opinions Recommendation

68. Wacker D, Wang S, McCorvy JD, et al:: Crystal Structure of an LSD-Bound Human Serotonin Receptor. Cell. 2017; 168(3): 377-389.e12. PubMed Abstract | Publisher Full Text | Free Full Text | Faculty Opinions Recommendation

69. Karaki S, Becamel C, Murat S, et al.: Quantitative phosphoproteomics unravels biased phosphorylation of serotonin $2 \mathrm{~A}$ receptor at Ser280 by hallucinogenic versus nonhallucinogenic agonists. Mol Cell Proteomics. 2014; 13(5): 1273-85. PubMed Abstract | Publisher Full Text | Free Full Text

70. Inoue A, Raimondi F, Kadji FMN, et al.: Illuminating G-Protein-Coupling Selectivity of GPCRs. Cell. 2019; 177(7): 1933-1947.e25 PubMed Abstract | Publisher Full Text | Free Full Text | Faculty Opinions Recommendation

71. González-Maeso J, Ang RL, Yuen T, et al.: Identification of a serotonin/ glutamate receptor complex implicated in psychosis. Nature. 2008; 452(7183): 93-7.

PubMed Abstract | Publisher Full Text | Free Full Text |

Faculty Opinions Recommendation

72. Fribourg M, Moreno JL, Holloway T, et al:: Decoding the signaling of a GPCR heteromeric complex reveals a unifying mechanism of action of antipsychotic drugs. Cell. 2011; 147(5): 1011-23.

PubMed Abstract | Publisher Full Text | Free Full Text |

Faculty Opinions Recommendation

73. Toneatti R, Shin JM, Shah UH, et al:: Interclass GPCR heteromerization affects localization and trafficking. Sci Signal. 2020; 13(654): eaaw3122. PubMed Abstract | Publisher Full Text | Free Full Text Faculty Opinions Recommendation

74. Murat $\mathrm{S}$, Bigot $\mathrm{M}$, Chapron J, et al:: $\mathbf{5}-\mathrm{HT}_{2 \mathrm{~A}}$ receptor-dependent phosphorylation of $\mathrm{mGlu}_{2}$ receptor at Serine 843 promotes $\mathrm{mGlu}_{2}$ receptor-operated $\mathrm{G}_{1 / 0}$ signaling. Mol Psychiatry. 2019; 24(11): 1610-26. PubMed Abstract | Publisher Full Text

75. Ahn S, Shenoy SK, Luttrell LM, et al.: SnapShot: $\beta$-Arrestin Functions. Cell. 2020; 182(5): 1362-1362.e1.

PubMed Abstract | Publisher Full Text | Faculty Opinions Recommendation 
76. Sutkeviciute I, Vilardaga JP: Structural insights into emergent signaling modes of G protein-coupled receptors. J Biol Chem. 2020; 295(33): 11626-42

PubMed Abstract | Publisher Full Text | Free Full Text | Faculty Opinions Recommendation

77. Lazar AM, Irannejad R, Baldwin TA, et al:: G protein-regulated endocytic trafficking of adenylyl cyclase type 9. Elife. 2020; 9: e58039. PubMed Abstract | Publisher Full Text | Free Full Text

78. Albert PR, Vahid-Ansari F: The 5-HT1A receptor: Signaling to behavior Biochimie. 2019; 161: 34-45.

PubMed Abstract | Publisher Full Text | Faculty Opinions Recommendation
79

Varrault A, Leviel V, Bockaert J: 5-HT1A-sensitive adenylyl cyclase of roden hippocampal neurons: Effects of antidepressant treatments and chronic stimulation with agonists. J Pharmacol Exp Ther. 1991; 257(1): 433-8. PubMed Abstract

80. D Jiang JY, Falcone JL, Curci S, et al.: Direct visualization of cAMP signaling in primary cilia reveals up-regulation of ciliary GPCR activity following Hedgehog activation. Proc Natl Acad Sci U S A. 2019; 116(24): 12066-71. PubMed Abstract | Publisher Full Text | Free Full Text |

Faculty Opinions Recommendation

81. Schou KB, Pedersen LB, Christensen ST: Ins and outs of GPCR signaling in primary cilia. EMBO Rep. 2015; 16(9): 1099-113. PubMed Abstract | Publisher Full Text | Free Full Text 